総説

\title{
偶感
}

\section{Stray Thoughts}

竹本實 $*$

TAKEMOTO Minoru※

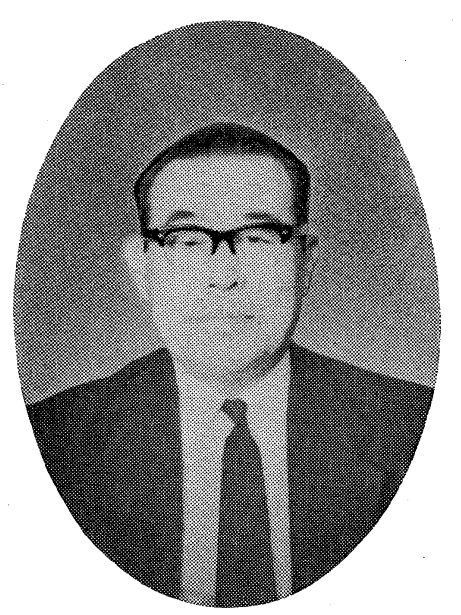

アルミニウムの1965年の生産量が全世界で約 6,000千 トン，日本においても約 300 千トンとなり，アルミニウ 厶は工業的に生産が始められた 1900 年から約60年間に 1,000倍，日本でも1955年から1965年の10年間には実に 5 倍と，他の金属に比べて驚異的な成長を示したこと は，よろこばしいことである。

この成長の過程をかえりみると，これだけの需要が開 拓されてきたのはなまやさしいことでなく，用途開拓に 異常の努力をされてきた軽金属工業界の先人の熱意に敬 意を表したい。

工業的に製造可能となつた新材料が，その需要を開拓 して行く過程を考えると, 次の二つが考えられる。

1 従来の材料では要求される性能が十分に満足できな かつた製品が，新材料の出現によつて画期的な性能向 上となる分野への進出。

2 既存の材料の性質と同程度だが、需要量の増大によ る操業規模の拡大，あるいは新材料の特性を生かすこ とによるデザインの変更などによつて，製品コストが 安価になるか，またはその製品が従来のものに比べて
有利な条件で使用できるなどの理由で, 新材料が従来の 材料の代替品的性格で進出する。

アルミニウムの成長過程もその例にもれず，まず軽い という特性で一部携帯品に使われているに過ぎなかつた が、新合金による強度、耐久性の向上によつて，航空機 の部品に使われ，さらにジュラルミンの出現によつて航 空機はアルミニウムが独占することになり，従来の木材 と布は完全に駆逐されてしまつた。

今日の航空機工業の発展はアルミニウムによつてもた らされたといっても過言でない。

さらに新合金による性質の向上，製造技術，需要拡大 にともなう製造規模の拡大による価格の低下によって代 替品的性格で家庭器物, 建材, 電機, 包装, 交通などの 平和産業への用途開拓のための努力が活発になされてき た。

敗戦によつて航空機方面への需要が閉ざされた日本で は，とくにこの傾向が著しい。

今後さらに技術進歩により, 安価かつ性能の向上によ つて, 代替品としてその用途が拡大していくにつれ, 既 存の材料との競合がますます激しくなつていくであろ 亏。

アルミニウムの競争相手としては鉄鋼, プラスチッ ク，木材などがある。

パネル，サッシュ，金網などの建材方面，船舶陸運な どの交通方面, 函, 缶, フイルム, 箔などの包装方面で のつばぜり合いはまことに峻烈なものがある。

アルミニウムは鉄鋼とプラスチツクの谷間にあるとい われているが，アルミニウムはその特性を生かして，交 通, 建材, 機械等方面で鉄鋼の分野に順次進出してきて いるが, 石油化学工業の発達による塩化ビニル, ポリ エチレン, ポリスチレン, A B S ポリプロピレンなど の新製品の出現によつて, 各方面でそれぞれの特色を生

* 住友化学工業株式会社軽金属事業部名古屋製造所長

General Manager. Nagoya Works, Light Metal Div. Sumitomo Chemical Co. Ltd. 
かして，プラスチツクも需要開拓をしている。

金属材料治度, 勒性, 耐劣化性, 耐熱性, 熱, 電気 の伝導性などでプラスチックに優位であり, 一方プラス チツクほ耐食性, 透明度, 着色性, 加工性, 比重などで 金属材料に優つており，今まではそれらを売物に需要を 開拓してきた。

しかし近年，プラスチツクは強度の点で軽金属にせま つてきている。F R P, ポリアセタール, ナイロン, A B S, ポリカーボネートの出現があり, さらに強化方法 として金属やセラミツクスのホイスカー配合が研究され ている。

従来アルミニウムは，強度が足りないことが鉄鋼製品 に比べてコスト高になる原因で障害にぶつかつていたこ とが多かつた。したがつて今後鉄鋼の分野への需要拡 大，プラスチックへの優位性を保つためにも安価でしか も高強度のアルミニウム合金の開発が望まれる。近年プ ラスチツクと複合板にすることによつて安価でしかも強 度の高いものが研究開発されているが，これも一法であ る。

アルマイト仕上げをしたアルミニウムは鉄鋼, プラス チツクに比べて耐久力があるが，その処理費用が高、欠 点がある。化学処理などの安価な方法によつてアルマイ トと同程度の耐食性のものがえられることが望ましい。 その一方法として近年プラスチックと協調して, 単一材 料の長所を組合せた新性能材料が開発されていることは 喜ばしい。すなわちラミネートとか被覆金属板の他に， 樹脂塗料の長足の進歩によつて, 加工性のよいカラーア ルミやカラートタンが生れている。化学工業や食品工業 で弱いアルカリ性の物質を扱うときに，金属製タンクや コンテナーは防食のコストが高価になつて困つていた が，樹脂塗料の応用で改善される。この方面にも順次ア
ルミニウムは用途を見出している。

次に接合について考えると，金属材料の場合はまずわ れにれは溶接，ロ一付け，リベット止めを考える。反対 に，プラスチツクの場合はほとんどの場合接着である。

金属用の接着剂は耐久性，耐熱性で未だしの感をもつ 人々も多いが，米国に抒いて航空機の軽合金部品を接着 剤で組立てることが研究されていると聞く。

軽金属は加工性の良いことを利用して，より複雑な形 状のものを作つたり，塗装板・被覆板・複合板のように プラスチックとの結合産物が，これから拉掠いに需要を 拡大する方向にあるときに，もう一度接着剤による接合 を考え直してみる必要があろう。この方面の開発はさら に鋳物，ダイカストのコストを下げるのにも役立つであ ろう。

このように，プラスチツクとアルミニウムはそれぞれ の特性を生かして各方面にその需要を拡大しているが, 必ずしも全面的に競合するものでなく，両者の組合せに よつてそれぞれの欠点を相補つたり,さらに各単独の場 合の性能より良い性能のものを見出すことも可能であろ う。接着剂も耐久, 耐熱性の良いものが開発されればア ルミニウムの製品のコスト低下, 需要拡大に㧍掠いに寄 与するであろう。

化学工業に籍を置くものとしては，この他にアルミニ ウムの製造設備の装置工業化, さらには板・管などの安 価な製造方法, 安価な表面処理法などの問題などいろい ろと考えさせられることが多い。

各種プラスチックをあわせて製造している化学会社 で，軽金属を扱つている一員として，最近のプラスチッ クの動向を見ながら，思いつくままに一文に記してみ た。 